\title{
References
}

Allan, J. R. \& Matthews, R. K. (in the press). Carbon and oxygen isotopes as diagenetic and stratigraphic tools: data from surface and subsurface of Barbados, West Indies. Geology.

Bathurst, R. G. C. 1959. The cavernous structure of some Mississippian Stromatactis reefs in Lancashire, England. J. Geol. 67, 506-21.

Bathurst, R. G. C. 1971. Carbonate Sediments and their Diagenesis. Developments in Sedimentology 12. Elsevier Scientific Publ. Co. xix +658 pp.

Davies, G. R. (1977). Former magnesian calcite and aragonite submarine cements in upper Paleozoic reefs of the Canadian Arctic: a summary. Geology 5, 11-15.

Kendall, A. C. \& Tucker, M. E. 1973. Radiaxial fibrous calcite: a replacement after acicular carbonate. Sedimentology 20, 365-89.

Ross, R. J., Jaanusson, V. \& Friedman, I. 1975. Lithology and origin of Middle Ordovician calcareous mudmound at Meiklejohn Peak, southern Nevada. Prof. Paper U.S. geol. Surv. 871, 48 pp.

Sander, B. 1936. Beiträge zur Kenntniss der Anlagerungsgefüge (rhythmische Kalke und Dolomite aus der Trias). Miner. Petrog Mitt. 48, 27-209.

Department of Geology

R. G. C. BATHURST

University of Liverpool

England

11 th January 1977

\section{Average calc-alkali basalt}

SIR - There is much discussion at present on the nomenclature of igneous rocks, in particular that of the I.U.G.S. Subcommission on the Systematics of Igneous Rocks (Streckeisen, 1976a), and we feel it may aid discussion to clarify the term 'Central' basalt and to present a revised average chemical composition for calc-alkali basalts.

Le Maitre (1976a) and Streckeisen (1976 b) discussed methods of classifying the rocks of the calc-alkali volcanic suite, and one problem encountered is to decide what is understood by the term calc-alkali basalt. In 1954 the term 'Central' basalt was introduced by Nockolds for basaltic rocks with labradorite or more calcic plagioclase, which are found in association with typical calc-alkali andesites, dacites and rhyolites such as occur at Lassen Peak and Mount Shasta in the Cascades, and in other central volcanic complexes of the Caribbean Arc and the circum-Pacific belt. It did not include the Mull Porphyritic Central Magma (or high-alumina) type of Bailey et al. (1924). The purpose was to distinguish calc-alkali basalts from the tholeiitic and alkaline basalts of anorogenic regions. The main features were higher $\mathrm{SiO}_{2}$ and $\mathrm{Al}_{2} \mathrm{O}_{3}$, and lower $\mathrm{MgO}$ and total Fe.

The term 'Central' basalt is now considered to serve no further useful purpose, and it is recommended that the term be abandoned. The basalts of this group should be and are better known as calc-alkali basalts.

A new average chemical composition of calc-alkali basalt has been compiled (by S.R.N.). It is calculated from 48 mostly newer analyses than were used for the 1954 average, and only those with a low $\mathrm{H}_{2} \mathrm{O}$ content, fresh mineralogy, reliable alkali determination, and with normative plagioclase $A n_{33}$ or greater are included. The new figures are only slightly different, and still indicate that calc-alkali basalts have relatively high $\mathrm{SiO}_{2}$ and $\mathrm{Al}_{2} \mathrm{O}_{3}$, and low $\mathrm{MgO}$ and total Fe figures compared with other basalts, but that the silica saturation, $\mathrm{Fe} / \mathrm{Mg}$ ratio, and iron oxidation ratio $\left(\mathrm{Fe}^{2+} /\right.$ total $\mathrm{Fe}$ atoms $\left.=0.70\right)$ are about the same as non-alkaline basalts (Le Maitre, 1976 b).

The composition of the normative plagioclase is $\mathrm{An}_{59}$, the differentiation index (Thornton \& Tuttle, 1960) is 30.1, and the crystallization index (Poldervaart \& Parker, 1964) is 51.7. The latter index may serve to distinguish calc-alkali basalt from overall average basalts which have c.i. $<50$, but the d.i. is the same (Le Maitre, 1976 b). The normative colour index is 34 which, when plotted against normative plagioclase composition, is below that for 'within plate' tholeiitic basalts (commonly in range 40-60), but coincides with that given for basalts from the Aleutians and Cascades by Irvine \& Baragar (1971).

The new average composition for calc-alkali basalts also responds well when subjected to principal component analysis using the three eigenvectors given by Le Maitre (1976 a, table 1$)$. The resulting three 
eigenvectors for the average calc-alkali basalt composition are $-37.1,-7.5$ and -9.9 respectively, and plot just off-centre, towards andesite, in both the basalt fields given in Le Maitre's density plot of basalts, andesites, dacites and rhyolites (1976 $a$, Fig. 1).

Table 1

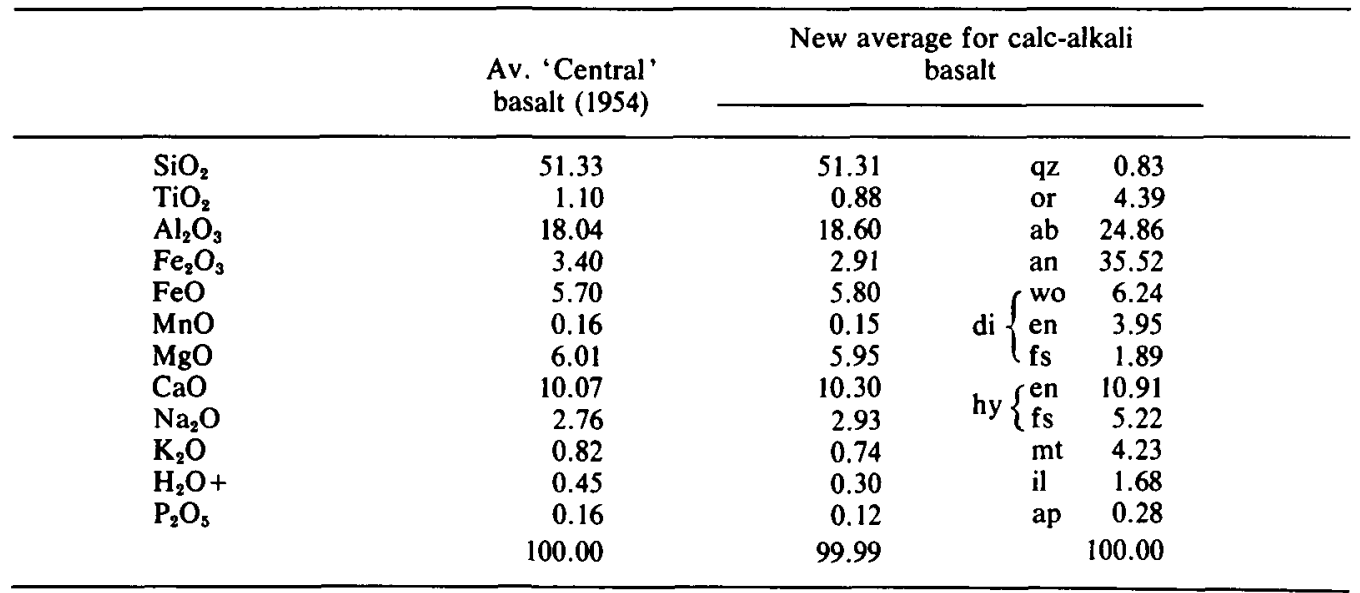

\section{References}

Bailey, E. B. et al. 1924. Tertiary and post-Tertiary geology of Mull, Loch Aline and Oban. Mem. geol. Surv. Scotland.

Irvine, T. N. \& Baragar, W. R. A. 1971. A guide to the chemical classification of the common volcanic rocks. Can. J. Earth Sci. 8, 523-48.

Le Maitre, R.W. 1976(a). A new approach to the classification of igneous rocks using the basalt-andesitedacite-rhyolite suite as an example. Contr. Miner. Petrol. 56, 191-203.

Le Maitre, R. W. 1976(b). The chemical variability of some common igneous rocks. J. Petrology 17, 589-637.

Nockolds, S. R. 1954. Average chemical compositions of some igneous rocks. Bull. geol. Soc. Am. 65, 1007-32.

Poldervaart, A. \& Parker, A. B. 1964. The crystallization index as a parameter of igneous differentiation in binary variation diagrams. Am. J. Sci. 262, 281-9.

Streckeisen, A. 1976(a). To each plutonic rock its proper name. Earth Sci. Rev. 12, 1-33.

Streckeisen, A. 1976(b). Classification of the common igneous rocks by means of their chemical composition. Neues Jb. Miner. Mh H.1, 1-15.

Thornton, C. P. \& Tuttle, O. F. 1960. Chemistry of igneous rocks: Pt. 1, Differentiation index. Am. J. Sci. 258, 664-84.

The Bell House, Castle Street

S. R. NOCKOLDS

Saffron Walden, Essex

Department of Geology

M. J. LE BAS

University of Leicester

University Road

Leicester, LE1 7RH

4th April 1977 